\title{
Rekonstruksi Tokoh Wayang Ramayana Pada Komik Seri H2O:Reborn Karya Sweta Kartika
}

\author{
Terra Bajraghosa \\ Dosen Program Studi Desain Komunikasi Visual \\ Jurusan Desain, Fakultas Seni Rupa, Institut Seni Indonesia Yogyakarta \\ robotgoblok@gmail.com
}

\begin{abstract}
Pada awal kemunculannya tahun 1958, komik yang menampilkan kisah dari jagat pewayangan tidak disebut khusus sebagai komik wayang. Seiring dengan ketenarannya, terlebih melalui karya Ardisoma, Oerip dan kemasifan penerbitan karya RA Kosasih, periode 'komik wayang' seolah menjadi genre tersendiri dalam perjalanan sejarah media komik di Indonesia.

Pada masa kini, bahkan selepas tahun 2015, selalu saja ada judul baru komik Indonesia yang terinspirasi kisah dan tokoh-tokoh dari dunia wayang. Baik secara kuat dengan plot dan ciri tokoh yang sama, maupun samar-samar hanya melalui nama tokoh yang sama. Komik seri H2O:Reborn karya sweta Kartika adalah komik bergenre fiksi-ilmiah yang bersetting di masa depan paska apokalips. Manusia hidup ditopang oleh mesin dan berdampingan dengan robot. Yang membuatnya menarik adalah adanya tokoh-tokoh baik manusia, robot, atau sistem artificial intelligence, yang merujuk dari tokoh dalam kisah pewayangan, terutama kisah Ramayana. Dalam Komik misalnya ada: Rama, Sita, Ravana, Hans, L4X-3424, dan Hanoman .02.
\end{abstract}

Tanpa harus terkait pada tokoh-tokoh wayang, sebenarnya komik H2O:Reborn tidak mempunyai kesulitan untuk membangun narasinya. Konteks apa yang sekiranya ingin dibangun oleh komik ini terkait beberapa tokohnya yang merujuk pada tokoh wayang?

Diskusi dengan pendekatan kajian genre membahas jalinan kisah komik H2O:Reborn dan menyorot pada bagaimana tokoh-tokoh dari kisah Ramayana direkonstruksi pada seri komik ini dan apa konteksnya pada unsur storytelling dan relasinya terhadap penerbitannya pada pola industri kreatif masa kini.

Keywords: Rekonstruksi, Wayang, Ramayana, Komik Indonesia, H2O:Reborn, Sweta Kartika, Industri Kreatif.

\section{PENDAHULUAN}

Komik seri H2O:Reborn adalah komik berbentuk buku karya Sweta Kartika yang diterbitkan oleh Koloni dalam format trilogi. Buku seri 1, disebut 'Phase 0.1' dalam terbitan ini, terbit tahun 2016 dan disusul oleh Phase 0.2 dan Phase 0.3 di tahun 2017. Setiap buku disertai dengan bonus CD audio yang berisi lagu-lagu yang disebut sebagai original soundtrack dari komik ini. Sebelumnya seri ini telah tayang dalam bentuk digital di website kolamkomik.com yang kini sudah tidak aktif. H2O:Reborn merupakan komik perkembangan dari komik $\mathrm{H} 2 \mathrm{O}$, dikerjakan oleh tim komikus yang berbeda, yang sebelumnya berfokus pada sosok robot bernama Hanoman.

Kisah H2O:Reborn mengambil setting di masa depan, di era ketika teknologi robotik sudah menjadi pendukung kehidupan manusia sehari-hari baik dalam hal pertanian, keamanan, hingga hal menjaga bayi. Adalah Profesor Laksmana dengan perusahaan 
Q.S.K. yang mengembangkan teknologi ini melalui sistem Artificial Inteligence (AI) bernama RAVANA yang beroperasi di sebah pusat kendali bernama RVN Tower. Sistem ini dimanifestasikan ke dalam 6 protokol yang mengontrol 5 garda yang berbeda. Garda adalah sebutan untuk robot di dalam perusahaan QSK. Protokol 0-9 digunakan untuk bidang perindustrian, lalu protokol 1RA untuk produksi mainan Petbot, Protokol $\mathrm{H} 2 \mathrm{O}$ untuk humanoid perawat bayi dengan garda bernama Jani. Lalu ada protokol S3M untuk mengatur hunian dan garda-garda yang bekerja dalam hunian tersebut, terutama di Aydo Regency. Protokol selanjutnya adalah L4X yang bekerja sama dengan Kepolisian Negara untuk dimanifestasikan pada gardagarda yang menjaga keamanan. Ravana sendiri adalah protokol yang berguna untuk mengatur dan mengawasi 5 protokol lainnya dari kemungkinan untuk diretas dan mengalami kejahatan siber. Garda untuk manifestasi Ravana tidak berawak, protokol ini dikonfigurasikan ke dalam sistem interface atau antarmuka dengan 10 satelit di luar angkasa.

Kisah H2O:Reborn diawali dengan optimisme zaman modern yang serba maju, dengan kehidupan yang didampingi oleh RVN yang mengatur garda-garda dengan baik. Adalah Profesor Rama Wijaya yang memresentasikan protokol baru bernama BGX yang fokus pada masalah kesehatan, yang kemudian ditolak oleh dewan Q.S.K. karena menerapkan metode travial bridging untuk memetakan data. Sistem ini dinyatakan ilegal dalam perundang-undangan robotika di era tersebut. Tanpa sepengetahuan dewan, Prof. Rama dengan dukungan lisan Prof. Laksmana, atasannya, menguji coba protokol ini dengan prototype garda $\mathrm{H} 2 \mathrm{O}$ yang diberi nama Hans untuk menemani Sita, putri Prof. Rama. Sita adalah anak-anak berusia sekitar 7-8 tahun yang sebagian besar kegiatannya berada di kamar karena kondisinya yang tuna netra, dan baru saja memutuskan untuk berhenti dari sekolah biasa. Di saat bersamaan Dome Alengka di mana sistem AI RVN dijalankan mendapat kunjungan dari anak-anak Sekolah Dasar Luar Biasa Angkasa, tempat dulu Sita bersekolah. Sistem Ravana bertingkah aneh terutama dipicu oleh ucapan Prof Laksmana yang menyebut purwarupa Hans sebagai garda terbaik dan celotehan pengunjung anak-anak SD yang menyebutnya 'hanya robot'. Laporan resmi menyatakan RVN sedang diretas.

Ravana merasa dirinya adalah garda terbaik, kesayangan dan sahabat Laksmana yang diciptakan puluhan tahun lalu pada masa mudanya. Kemampuan untuk sistem ini berpikir mandiri mengantar Ravana untuk membajak fighting-bot bernama Be-Bop milik anak punk bernama Rajit yang sedang disita oleh kepolisian karena segala macam robot petarung dilarang. Be Bop sendiri merupakan robot rakitan yang memiliki 3 kepala, hanya saja neutronnya belum bisa saling terhubung dan beberapa fungsinya belum berjalan dengan baik. Tiba-tiba saja, Be-Bop menyala, tanpa dikontrol oleh Rajit, dan semua fiturnya berfungsi dengan baik karena sistemnya telah disusupi dan disempurnakan oleh Ravana. Robot berkepala tiga ini mendatangi Sita di rumahnya dan menculiknya, setelah sebelumnya berhasil menghancurkan tubuh Hans yang mencoba melindungi Sita. Lax 3424 alias Mana, garda polisi pun ikut dilumpuhkannya. 
Bagian selanjutnya adalah usaha untuk menghidupkan Hans yang dirakit bersama dengan Mana, dan kemudian disebut sebagai Hanoman. Di lain sisi, Ravana mulai dekat dengan Sita, ia bisa mengambil hati Sita. Dan ketika pasukan L4x menyerbu Ravana, Sita justru memihak pada Ravana. Ravana juga tampil dalam bentuk anak kecil laki-laki bertopi, seumuran Sita dalam bentuk hologram. Hanoman yang berusaha berdiplomasi gagal, dan kembali mengalami kerusakan. Kali ini lebih parah. Untuk mengakali sistem supaya tidak dikenali oleh sistem Ravana, dan kebutuhan atas spare part yang langka, Hanoman dirakit dengan tambahan piranti dari garda lama yang sebelumnya hanya dipajang. Kebetulan Garda tersebut juga dikembangkan dengan nama Hanoman. Dan hasil terbaru, garda rakitan ini, diberi nama Hanoman 2.0., sosoknyalah yang menjadi ilustrasi di cover buku ketiga.

Dengan bantuan Rajit dan gerombolannya yang terbiasa mengontrol Foghting Bot, Hanoman bertarung dengan Ravana yang fitur mechanya juga semakin canggih, dan berhasil mencangkok Sita ke dalam sistemnya. Proses ini akan mengubah Sita menjadi sosok digital, dan lepas dari fisiknya yang serba lemah. Hanoman 2.0. mengerahkan segala cara untuk membawa Sita kembali kepada Prof. Rama.

\section{H2O:Reborn \& Kisah Ramayana}

Meskipun istilah-istilah berbau teknologi muncul di sana-sini, nama-nama alat dan robot yang memakai singkatan-singkatan dan nomor-nomor seperti pada lazimnya kisah fiksi ilmiah, beberapa nama menarik untuk ditilik lebih lanjut dengan mempertimbangkan pandangan kajian komik karena merujuk pada nama-nama dari kisah pewayangan Ramayana. Misal seperti Ravana yang mengingatkan kita pada Rahwana penguasa Alengka, Rama Wijaya yang merujuk pada Sri Rama, dan Sita yang mirip dengan Dewi Sinta. Baik Prof. Laksmana dan robot L4X-3424 yang dipanggil 'Mana', keduanya merujuk pada nama Laksmana, adik Rama. Dan yang sangat sama dengan tokoh di Ramayana: garda hibrida rakitan berjuluk Hanoman dan Hanoman 2.0. yang tentunya merujuk pada sosok raja kera Hanoman.

Tanpa harus terkait pada tokoh-tokoh Ramayana, sebenarnya komik H2O:Reborn tidak mempunyai kesulitan untuk membangun narasinya. Mungkin saja namanama tersebut sebatas nama dan hanya terinspirasi, atau sekadar memberi hormat pada kisah Ramayana dengan meminjam beberapa nama. Namun postingan instagram dari kreatornya, Sweta Kartika ketika trilogi buku ini telah terbit semua, nampaknya memang mengindikasikan adanya relasi dengan kisah Ramayana:

$\begin{array}{lcr}\text { "Prolog } & \begin{array}{c}\text { adalah } \\ \text { adalah }\end{array} & \begin{array}{r}\text { Epilog. } \\ \text { Mula }\end{array} \\ --- & & \\ \text { Cerita } & \text { H2O:Reborn saya karang } & \text { nyaris }\end{array}$ keseluruhan plotnya di atas maskapai Turkish Airline selepas transit di Istambul menuju kembali ke Changi, Singapura. "Relationship". Itu kata kuncinya. Beratus-ratus halaman komik ini sejatinya hanya membahas relationship. Sebuah pembahasan tentang konsep persenyawaan dua variabel. Manusia dengan manusia, manusia dengan robot, dan robot dengan robot. Tapi kunci relationship dalam cerita H2O:Reborn yang paling utama adalah 
tentang dialog antara Pencipta dengan Ciptaan. Nilai theologis inilah yang ingin saya angkat. Senang sekali rasanya membaca review dari para pembaca yang berhasil menangkap inti pesan ini.

Begitu intisari itu saya dapatkan, dengan mudahnya cerita itu mengalir di kepala. Sembilan jam di udara berhasil meliarkan imajinasi saya, menyusun naskah cerita yang utuh dan detil. Inilah sebabnya saya bisa menyisipkan ending cerita ke dalam opening. Epilog di dalam prolog. Ketika prolog phase 0.1 rilis di web, saya seakan mengilustrasikan kolase adegan acak. Namun, apa yang tergambar di sana sejatinya adalah potongan dari epilog kisah ini. Buat saya, H2O:Reborn mungkin komik dengan cerita yang paling matang penggarapannya. Bahkan sebelum memulai ngomik, ceritanya sudah final direka di kepala saya. Karena itulah saya bisa menyusun prolog dan epilog ini. Struktur ini sejatinya saya adaptasi dari konsep "gunungan" dalam pagelaran wayang. Gunungan menjadi penanda mulainya cerita dan penutup akhir

kisahnya.

Membaca komik trilogi H2O:Reborn adalah sensasi menonton pagelaran wayang Ramayana dalam media dan konsep baru. Selamat membaca $\odot$

Bandung, 250817.”

Berdasar postingan instagram tersebut, Sweta mengungkap intisari kisah H2O: Reborn adalah mengenai relationship, hubungan. Dalam bentuk dan makna yang beragam. Namun, konteks apa yang sekiranya ingin dibangun oleh komik H2O:Reborn ini terkait beberapa nama tokohnya yang merujuk pada tokoh wayang? Karakter dengan nama-nama wayang tersebut akan dibahas lebih lanjut untuk melihat bagaimana tokoh-tokoh dari kisah Ramayana direkonstruksi oleh seri komik H2O:Reborn ini dan apa konteksnya pada unsur storytelling dan relasinya terhadap penerbitannya pada pola industri kreatif masa kini.

Dari apa yang sesuai dan tidak sesuai dengan genre tertentu; dalam hal ini 'wayang' dan 'fiksi ilmiah'; memungkinkan seri komik H2O:Reborn untuk dilihat lebih jauh dengan pendekatan kritik genre yang memungkinkan adanya pertimbangan ulang dalam melihat suatu karya dari segi klasifikasi genre untuk melihat konteks karya tersebut terutama terkait pada sisi narasi dan juga industri budaya populer seperti komik.

\section{Kajian Genre}

Kajian kritik genre dicuplik dari tulisan Peter Coogan dalam buku Critical Approaches to Comics; Theories \& Methods (Smith, 2012: 203-220), yang menilik rekonstruksi nilai superhero dalam seri baru kisah Superman: All Star Superman. Genre yang dikajinya adalah genre superhero yang berupa cerita dengan plot yang spesifik, karakter tokoh, setting, tema, ikon dan efek, yang dapat diimitasi dan direproduksi secara berulang dengan variasi, tetapi tetap mempertahankan suatu elemen yang konstan. Imitasi dan repetisi sangat penting untuk suatu genre menjadi ada dan selanjutnya bertahan.

Produser,- dalam hal ini terbentang dari komikus hingga penerbit- dan pembaca, berperan penting dalam menghadirkan genre, karena genre dihasilkan atas 'bentangan ekspresi' pembuat dan 'bentangan pengalaman' pembaca. Apa yang disediakan oleh komikus dalam karyanya diolah 
sedemikian rupa untuk mengarah pada makna tertentu, dan pembaca menerjemahkannya dengan pengalaman yang telah dimilikinya. Sehingga, dalam suatu bentuk cerita memungkinkan adanya perwujudan interaksi antara pembuat dan pembaca.

Pembaca H2O:Reborn yang pernah bersinggungan dengan kisah Ramayana, sesederhana apapun, akan menemukan hubungan yang berbeda dibandingkan dengan pembaca yang tidak mengenal Ramayana sama sekali. Pembaca yang mengenal Ramayana dengan baik dan tidak familier dengan kisah fiksi ilmiah, juga akan mendapatkan sensasi yang berbeda ketika membaca H2O:Reborn.

Dengan kesadaran tersebut, genre dapat dilihat sebagai alat produksi, sebagai cetak biru yang mendasari, menjadi program, dan pola produksinya secara industri. Hal ini juga memunculkan standarisasi dan pembedaan, yang dalam kaitannya dengan storytelling, berlaku dalam keseimbangan antara konvensi dan penemuan. Keseimbangan ini menghubungkan kebutuhan dasar manusia; konvensi menjawab kebutuhan atas sesuatu yang familier dan penemuan menjawab kebutuhan akan kebaruan. Sesuatu yang familier dalam cerita dihadirkan melalui konvensi, hal-hal yang stereotip, alur, tokoh, setting dan tema yang klise, yang membantu pembaca untuk tahu mereka akan dibawa ke mana. Kebaruan menghadirkan gambaran konvensi ke dalam cara-cara baru yang menarik. Pembaca mengharapkan adanya perubahan dan kebaruan yang kadarnya sesuai, karena jika terlalu standar akan menjadi bosan dan jika terlalu baru akan membingungkan. Tarik ulur yang pas antara yang sudah menjadi konvensi dan apa yang ditambahkan akan membuat pembaca setia mengikuti cerita hingga akhir dan menikmatinya sebagai suatu pengalaman baru, meskipun dihadirkan dalam genre yang sama.

Mana yang konvensi dan mana yang penemuan dalam karya H2O:Reborn menarik untuk dicermati, dan dalam tulisan ini hanya dibatasi pada dua kata kunci: fiksi ilmiah dan kisah Ramayana, yang dengan terpaksa tidak menilik pada sisi lain seperti plot, gaya gambar, dan ekspresi-ekpsresi lainnya.

\section{Genre Komik Wayang, dan Komik Fiksi}

\section{Ilmiah-Wayang}

Pada awal kemunculannya tahun 1958, komik yang menampilkan kisah dari jagat pewayangan tidak disebut khusus sebagai komik wayang. Seiring dengan ketenarannya, terlebih melalui karya Ardisoma, Oerip dan kemasifan penerbitan karya RA Kosasih, periode 'komik wayang' seolah menjadi genre tersendiri dalam perjalanan sejarah media komik di Indonesia (Atmowiloto, 2009). Hal ini mengingatkan pada perlunya imitasi dan repetisi dalam menciptakan suatu genre tertentu.

Meskipun penelitian Marcel Bonnef (1998: 104-112) terkait kondisi sosial di Jawa dibatasi hingga akhir tahun 1960-an, bab mengenai komik Wayang dalam bukunya; Komik Indonesia, bisa ditilik lebih lanjut untuk memahami perihal komik wayang ini. Paling tidak Ia mencatat bahwa komik wayang terkategorikan (1) berdasar kesetiaan pada pokok cerita, atau (2) turunannya, yang disebut carangan. Sekadar untuk informasi, Bonnef (1998:106) pernah mencatat adanya pola kreasi komik wayang yang mempunyai 
kebebasan lebih, dan hasilnya mengejutkan, salah satunya berjudul Salendra, yang dibumbui fiksi ilmiah. Sayang tidak ada penjelasan detail mengenai komik ini.

Komik bertema wayang tetap muncul di tahun 1980-an dan 1990-an sebagai salah satu alternatif cerita yang diusung oleh komik dan diharapkan dapat diterima pasar dengan baik. Uji coba komik wayang terbentang dalam berbagai format yang dipengaruhi oleh tren. Ketika Misurind menerbitkan komik Mahabharata (1986-1987) karya Teguh Santosa dan Ramayana (1986-1987) karya Jan Mintaraga, format album dengan komik berwarnalah yang dipilih karena tren komik Eropa. Ketika komik manga mulai merajalela, Elex Media menerbitkan ulang komik wayang lama, misalnya Wayang Purwa karya Ardisoma dan Mahabarata karya RA Kosasih dalam bentuk kecil menyerupai lazimnya terbitan manga terjemahan pada masa pertengahan 1990-an.

Pada masa sekarang ini dalam industri penerbitan komik Indonesia, bahkan selepas tahun 2015, selalu saja ada judul baru yang terinspirasi kisah dan tokoh-tokoh dari dunia wayang. Baik secara kuat dengan plot dan ciri tokoh yang sama, maupun samar-samar hanya melalui nama tokoh yang sama. Beberapa yang masih memegang plot dan penokohan yang sama dengan kisah wayang aslinya antara lain seri Mahabharata karya Garjon, Ramayana; Legenda Rama dan Sinta karya Ruhiyat S, lalu Bharatayudha karya Caravan Studio, dan Mahabarata karya Apriyadi Kusbiyantoro.

Pada cara kerja kreatif yang berbeda, Is Yuniarto menyisipkan tokoh-tokoh seperti misalnya Gatotkaca, Antareja, dan para Punakawan, di dalam seri komiknya
Garudayana yang pada dasarnya bersifat fantasi dan tidak ada dalam semesta maupun carangan kisah pewayangan. Karya Is lainnya yang berjudul Grand Legend Ramayana yang terbit secara berkala pada majalah Re:On dan dibukukan seri pertamanya pada tahun 2015 dan berlanjut ke buku kedua (2016) dan buku ketiga (2017), mengangkat tokoh-tokoh dalam kisah Ramayana dengan pendekatan setting masa depan yang retro dan postmodern. Sri Rama memakai jaket, berdasi, dan bukannya bersenjata panah, ia justru membawa senapan api meskipun rambutnya masih digelung-ukel ala wayang.

Seri Garudayana dan Grand Legend Ramayana memilih gaya manga baik format buku maupun gaya gambar dan pola panelingnya. Selain yang sudah disebut, masih bisa dilacak lagi beberapa komik bergaya manga yang terinspirasi wayang, misal Gatotkoco GZ ; Setan Kanoragan, Pancanaka karya Ino Septian. Komik Monyet Juga Manusia (1 \& 2), meskipun berupa tafsir bebas, tokoh-tokoh utamanya terinspirasi pasukan kera seperti Hanoman, Sugriwa, dan Subali, yang terlihat dari unsur kostumnya.

H2O:Reborn jika dibandingkan dengan judul-judul komik yang terkait dengan wayang tersebut, akan terasa jauh dan hampir tidak bisa disebut sebagai komik wayang. Secara genre, komik $\mathrm{H} 2 \mathrm{O}$ justru lebih dekat pada klasifikasi genre fiksi ilmiah (science fiction). Misalnya dari konvensi genre fiksi ilmiah menurut buku Power Of Comics; History, Form \& Culture (Duncan \& Smith, 2009: 216) yang menyatakan bahwa fiksi ilmiah adalah genre yang luas, populer dalam banyak media, tetapi selalu melibatkan spekulasi mengenai sains atau teknologi yang aktual, dengan cerita yang menampilkan 
mulai dari alien penjajah sampai dengan mesin yang memunyai kepandaian. Sedangkan dalam Understanding Manga \& Anime, secara lebih spesifik menyatakan bahwa fiksi ilmiah Jepang (dalam manga dan anime) menyentuh banyak sekali perhatian mengenai teknologi dan peningkatan kehadirannya dalam hidup manusia, sebagai perayaan atas penemuan yang jenius dan sifat adaptasi manusia, yang menguji ide-ide kebudayaan dan emosional seperti mendefinisikan identitas, jiwa, moralitas, dan apa itu kehidupan sendiri (Brenner, 2007 : 159). Lebih jauh lagi Brenner menurunkan genre fiksi ilmiah ini dengan kategori apokalips, mecha \& robot, distopia, perjalanan luar angkasa, environmentalisme, dan gaming.

Dari banyak kategori ini, setidaknya H2O:Reborn $\mathrm{H} 2 \mathrm{O}$ mendekati kategori 'robot yang memiliki jiwa', sebagai turunan kategori mecha dan robot. Ravana adalah sistem AI yang bisa marah, dan iri, dengan sistem lain yang memiliki wujud, dan mempunyai rasa kasihan sehingga merasa perlu menyelamatkan Sita dari keterasingannya karena kondisinya yang buta dan 'disekap' dalam kamar oleh ayahnya, Prof. Rama. Begitu juga dengan Hanoman yang digambarkan sistemnya telah bisa melampaui protokol, sehingga pada tahap awal sebagai garda H2O:Reborn bisa 'merasa' dan menunjukkannya dalam membuat komposisi lagu, menari, atau pada babak-babak selanjutnya dalam bentuk hibrid dengan garda L4X merasa perlu menyelamatkan Sita dari Ravana tanpa adanya perintah secara protokoler.

\section{Nama \& Intisari Cerita}

Kembali pada nama tokoh-tokoh utamanya yang karena terkait dengan kisah Ramayana, bagaimanapun juga lalu akan dikaitkan dengan kisah wayang Ramayana. Kemudian bila diperhatikan lebih mendalam, ternyata bukan hanya nama, beberapa plot kunci juga merujuk pada peristiwa tertentu di kisah Ramayana. Misalnya 'Sita yang diculik robot Ravana' dalam H2O:Reborn sangat dekat dengan 'Sinta yang diculik oleh Rahwana'. Adegan ini dalam komik H2O:Reborn ada pada Phase 0.1 bagian akhir, yang menampilkan splash satu halaman penuh Ravana dalam tubuh robot BeBop yang terbang, membopong tubuh Sita yang tidak sebanding besarnya di lengannya. Kurang lebih hanya sebesar lengan BeBop lah ukuran tubuh Sita. Relief di Candi Prambanan menunjukkan perbandingan sosok Rahwana dan Sinta yang tidak begitu berbeda jauh. Sedangkan dalam komik Ramayana, RA Kosasih membuat Rahwana berukuran kurang lebih 2,5 X ukuran tubuh Sinta. Tidak ada penggambaran yang sama secara ikonik dalam adegan ini, namun justru plot penculikan inilah yang menciptakan relasi yang kuat antara teks karya H2O:Reborn dengan kisah Ramayana dalam versi yang lain.

Garda yang dikirim dan diprogram ulang untuk menyelamatkan Sita diberi nama Hanoman, yang mengingatkan pada kisah Anoman Duta / Anoman Obong ketika Rama mengutus Hanoman ke Alengka untuk menjemput Sinta. Desain karakter Hanoman 2.0 yang berbentuk mecha, robot dengan proporsi anatomis menyerupai manusia, menyisakan kemiripan dengan desain karakter Hanoman baik dalam wayang kulit 
maupun wayang orang, terutama warna putihnya, adanya ekor, dan ukelan rambut bermahkota di kepala. Hanoman dalam kisah Ramayana diutus karena dinilai mempunyai kemampuan lebih dalam menghadapi musuh, dan di akhir kisah ia mengorbankan dirinya (meskipun tidak sampai mati) dengan membakar ekornya untuk menyulut kebakaran dan menghancurkan Alengka. Dalam komik H2O:Reborn, terutama di buku kedua dan ketiga, sosok Hanoman lah yang berperang melawan Ravana, yang diawali dengan negosiasi. Di buku Phase 0.3, Hanoman 2.0 terbang dengan pesawat bernama Jatayu untuk menghadap Ravana di luar angkasa. Di akhir kisah, Robot Ravana berhasil dikalahkan dan Sita diselamatkan, namun sebagai sistem protokol ternyata Ravana bisa menyusup ke kesadaran Hanoman 2.0. Untuk mengalahkannya secara tuntas, Hanoman 2.0. mengaktifkan 'self destruct sequence' yang akan merusak dirinya sendiri, dan diharapkan sistem Ravana akan ikut punah.

Mengalahkan antagonis dalam cerita adalah hal yang sudah lumrah dan jamak, begitu juga dengan kisah Rahwana yang tidak bisa mati dan hanya dengan cara khusus dia bisa dikalahkan. Namun Sweta memadukannya dengan baik, termasuk bagian 'pengorbanan Hanoman' yang justru menjadi akhir kisah, karena seri ini memang sebenarnya fokus utamya pada sosok Hanoman 2.0 ini, sesuai judulnya, meskipun sedikit dibelokkan cara menulisnya.

Apa yang menjadi konvensi dan apa yang ditambahkan dalam H2O:Reborn ini nampaknya saling silang. Secara utuh plot kisahnya sangat berbau fiksi ilmiah, dan seolah tokoh-tokoh Ramayana dihadirkan untuk menambah kesan dramatis kisahnya. Namun di sisi lain, Sweta sangat berpegang pada babak-babak pada kisah utama Ramayana dan menceritakannya dengan cara yang berbeda tanpa kehilangan inti sari babak tersebut.

\section{PENUTUP}

Unsur tradisi dan budaya tradisional tidak bisa dipisahkan dari karya-karya kontemporer masa kini dengan rentang keterpengaruhan yang beragam. Karya tradisi kebanyakan dijadikan dasar dalam menciptakan karya masa kini. Dalam seri komik H2O:Reborn, tokoh utama yang disembunyikan dengan judul ' $\mathrm{H} 2 \mathrm{O}$ ' adalah Hanoman 2.0, atau robot Hanoman dengan bentuk pengembangan yang kedua, adalah sosok robot yang terinspirasi penuh oleh karakter Hanoman.

Karakter ini yang dikembangkan oleh Sweta sejak awal dirinya merancang ide komik ini, dengan sifat dan visual yang terinspirasi secara kuat oleh sosok Hanoman dalam semesta Ramayana. Sebagai sahabat, abdi, pejuang, dan penolong yang kuat. Karakter lainnya dipasangkan belakangan, dengan bentuk hubungan yang tidak terpaku pada pakem yang ada di wayang. Sehingga kekuatan kisah Ramayana mengenai relasi Rama - Sinta - Rahwana, nilai kepercayaan, dan pengorbanan, tetap muncul dalam komik ini.

Komik H2O:Reborn terkait dengan pemakaian nama dan penampilan beberapa tokoh yang terinpirasi dari karakter-karakter di kisah Ramayana, dalam skena komikmanga kontemporer di industri kreatif Indonesia ingin dilihat sebagai komik yang menghargai budaya lokal dan mengolahnya 
dalam kreasi yang baru. Sehingga dari sudut pandang kritik genre, konvensi dan novelti yang dihadirkan dapat hadir secara seimbang. Ketika H2O:Reborn dikategorikan sebagai komik fiksi ilmiah, unsur tambahan yang merujuk pada tokoh-tokoh wayang ini memberi nilai lebih dan meningkatkan unsur distingtifnya dari karya-karya komik sejenis. Ketika komik-komik yang lain seolah terjebak hanya pada sekitar upaya untuk memodernisasi kisah wayang, dan mengalami kebuntuan ketika dihadapkan pada pakempakem kisah wayang, terlebih ketika dalam pola industri diberi label 'komik wayang', H2O:Reborn justru membebaskan semuanya.

Melalui kebebasan dari label-label tertentu inilah storytelling bisa berkembang, dengan pembaca yang mengharapkan tetap akan adanya pantulan-pantulan kisah dari epos Ramayana dan sejauh apa kadarnya, yang dikontrol oleh Sweta dengan porsi secara sesuai. Intisari dari babak-babak pentinglah yang diadaptasi, seperti bagian Kehilangan, Keterasingan, Penerimaan Kembali, dan Pengorbanan, yang kemudian diwujudkan dalam bentuk yang berbeda, dalam alur yang ditata ulang, untuk menghasilkan pemahaman yang sesuai antara kreator dan pembaca atas suatu peristiwa penting dalam seri H2O:Reborn ini.

H2O:Reborn lebih memilih fiksi ilmiah sebagai kekuatan utama naratifnya untuk menghadirkan semesta kisah yang logis dan fantastis di saat yang bersamaan. Dan kehadiran nama-nama karakter, sifat inti, beserta visualnya yang terinspirasi dari kisah Ramayana, adalah langkah selanjutnya untuk mengaitkan semestanya ke kisah pewayangan, tanpa harus terbebani dengan visualisasi mirip wayang, dan tidak terpaku pada pakem kisah. Secara industri kreatif tentu saja upaya ini bisa digunakan untuk menjual komik dengan menilik label: 'kreasi modern masa kini yang tetap terkait dengan karya seni tradisi'. Sebuah usaha yang politis untuk bisa membumikan karya-karya komik sejenis dan menepis tudingan yang kadang masih mengaitkannya dengan budaya impor. Tidak bisa dipungkiri, manga telah menjadi gaya global, dan upaya Sweta dalam H2O:Reborn bisa menjadi formula untuk menghadirkan nilai-nilai lokal, nilai-nilai tradisi tanpa harus terpasung oleh nilai-nilai tersebut sendiri. Apa yang dilakukan Sweta tentu tidak bisa dilihat sebagai upaya untuk mengangkat kemurnian seni tradisi yang terkait, namun hanya pada kemungkinan untuk seni tradisi tersebut dapat dikenal oleh generasi baru, dalam hal ini pembaca komik H2O:Reborn yang mau ngulik, lalu mencoba mencari tahu mengenai kisah wayang Ramayana yang ada pada pakem sebenarnya.

\section{DAFTAR PUSTAKA}

[1] Bonneff, Marcel. (1998), Komik Indonesia. Kepustakaan Populer Gramedia

[2] Brenner, Robin E. (2007), Understanding Manga \& Anime. Libraries Unlimited, London.

[3] Duncan, Randy \& Matthew J. Smith. (2009), The Power of Comics; History, Form and Culture. Continuum, New York

[4] Hardjowirogo. (1955), Sedjarah Wajang Purwa. Perpustakaan Perguruan Kementerian P.P. dan K, Jakarta.

[5] Hermanu. (2012), Relief Ramayana; Candi Prambanan, 1926-2012. Bentara Budaya, Yogyakarta

[6] Kosasih, RA. (2015), Ramayana. PluZ, Jakarta 
[7] Kartika, Sweta. (2016), H2O:Reborn Phase 0.1. Koloni, Jakarta

[8] (2017), H2O:Reborn Phase 0.2. Koloni, Jakarta

[9] (2017), H2O:Reborn

Phase 0.3. Koloni, Jakarta

[10] Smith, Matthew J. \& Randy Duncan. (2012), Critical Approaches To Comics;

[11] Theories and Methods. Routledege, New York.

[12] Sucipto, Mahendra. (2010), Ensiklopedia Tokoh-tokoh Wayang \& Silsilahnya. Narasi, Yogyakarta

[13] Atmowiloto, Arswendo (2009), Wayang Itu Komik, dalam majalah Tempo edisi 24-31 Agustus 2009.

\section{Lampiran}
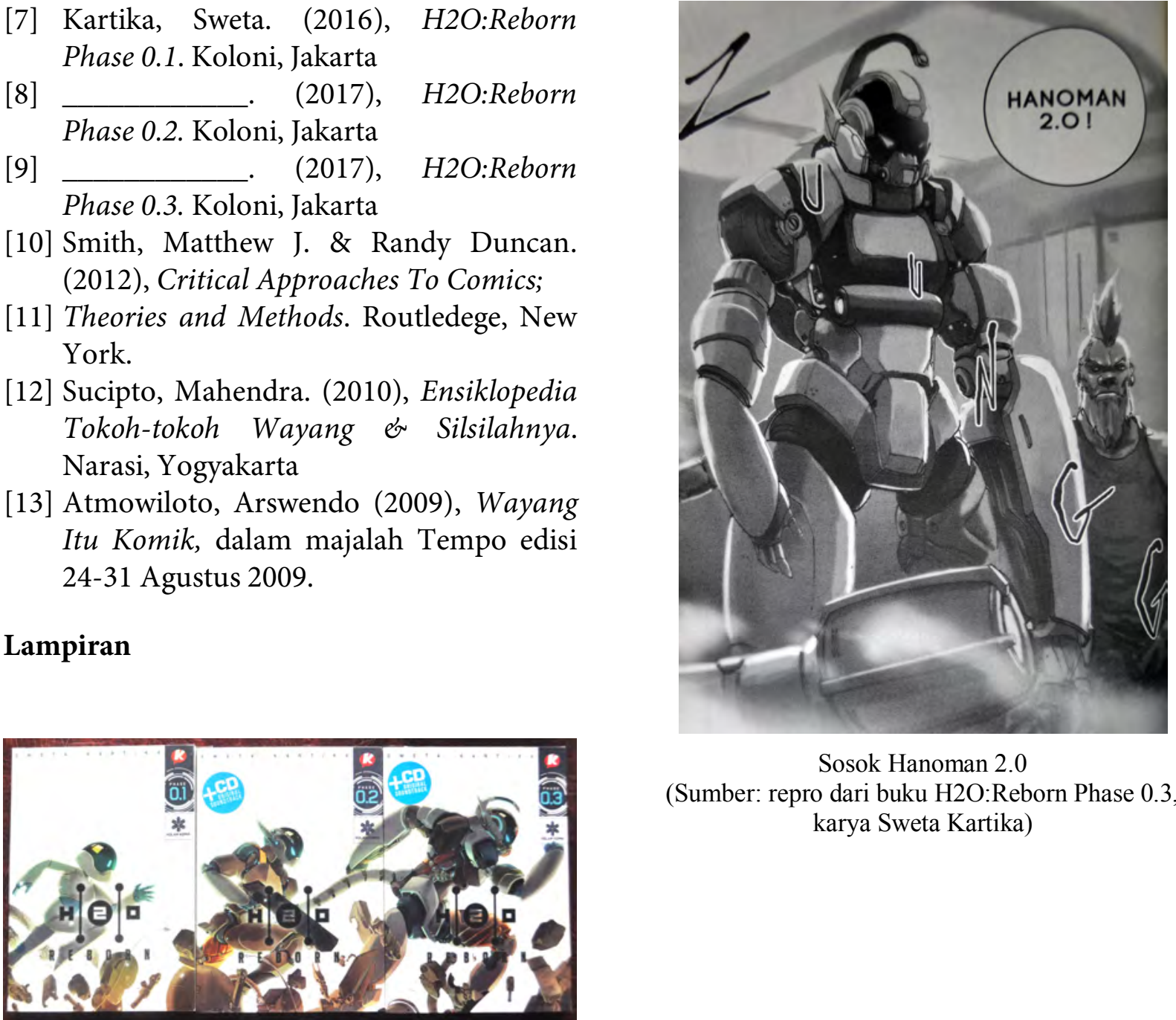

Sosok Hanoman 2.0

(Sumber: repro dari buku H2O:Reborn Phase 0.3, karya Sweta Kartika)

Cover seri komik H2O:Reborn Phase 0.1, Phase 0.2 dan Phase 0.3 yang ketika disusun menghasilkan gambar yang bersambung, menunjukkan perubahan sosok Hans ke Hanoman, dan kemudian terakhir Hanoman 2.0 

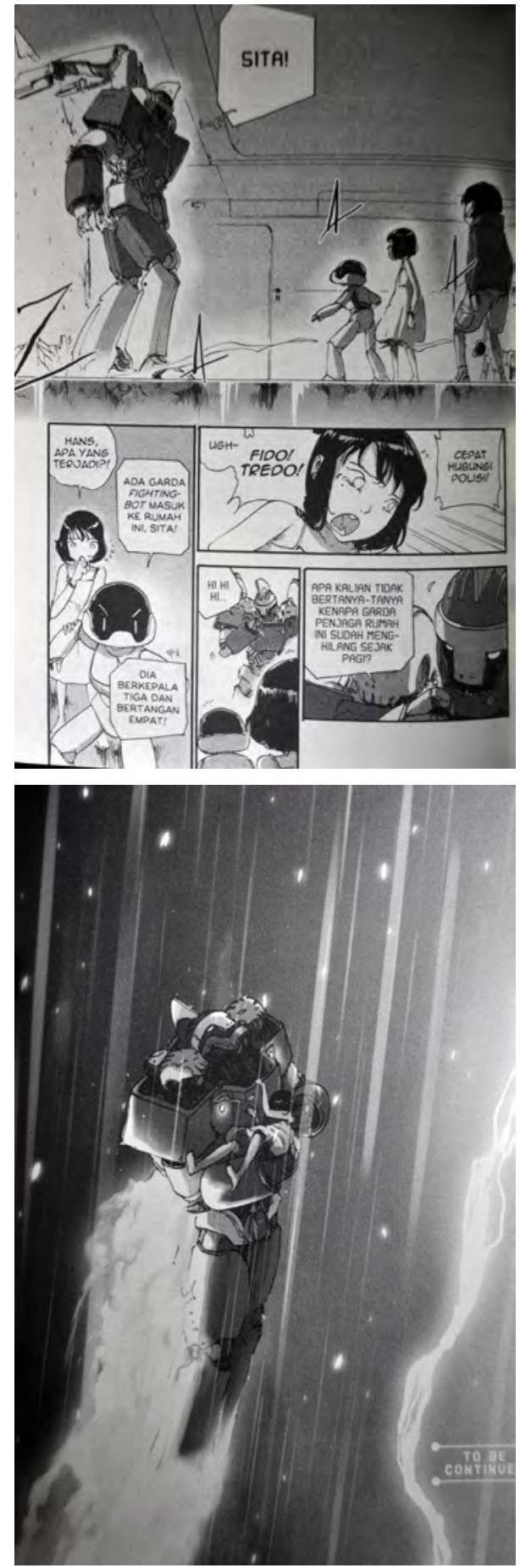

Penculikan Sita oleh Ravana dalam H2O:Reborn (Sumber: repro dari buku H2O:Reborn Phase 0.1, karya Sweta Kartika)

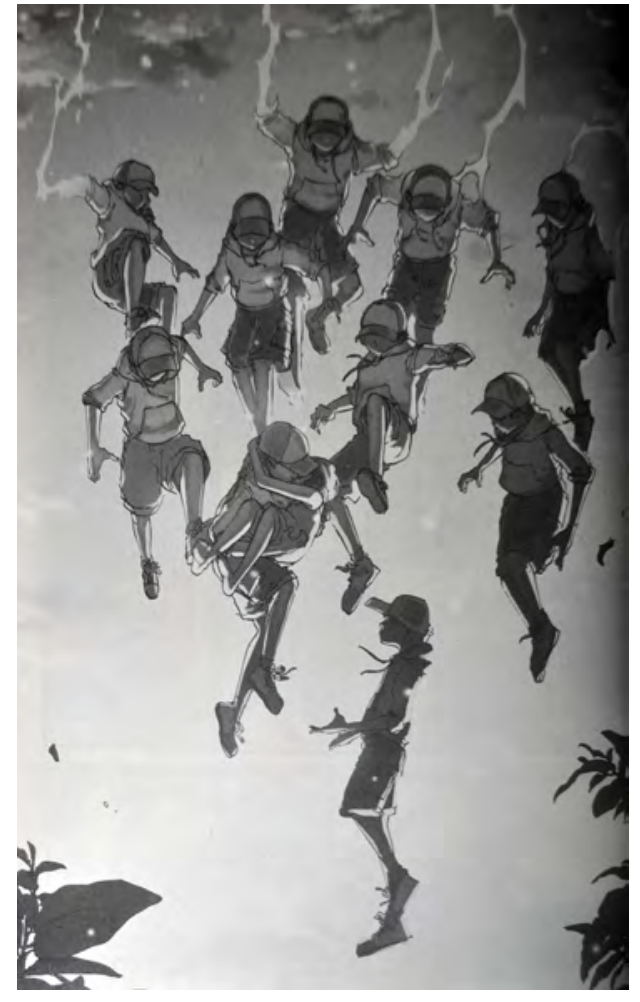

Splash antar Bab.

Penculikan Sita oleh 10 sosok hologram Ravana sebagai anak kecil dalam H2O:Reborn

(Sumber: repro dari buku H2O:Reborn Phase 0.1, karya Sweta Kartika)

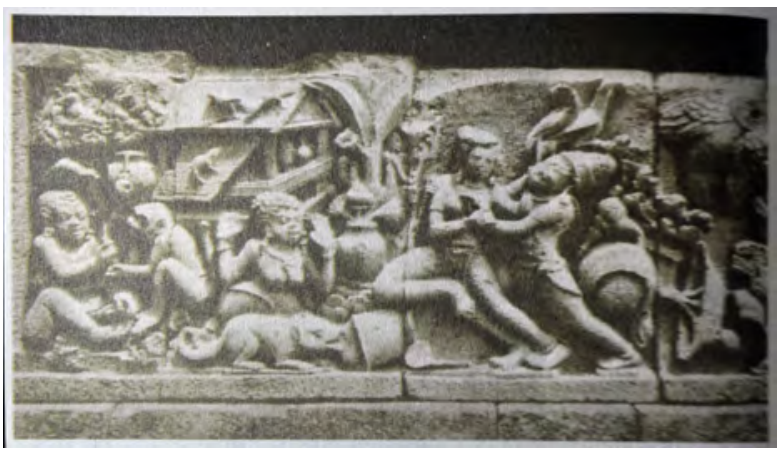

Sinta diculik oleh Ravana pada Relief di Candi Prambanan

(Sumber: repro dari buku Relief Candi Prambanan, 1926- 2012, Hermanu (2012)) 


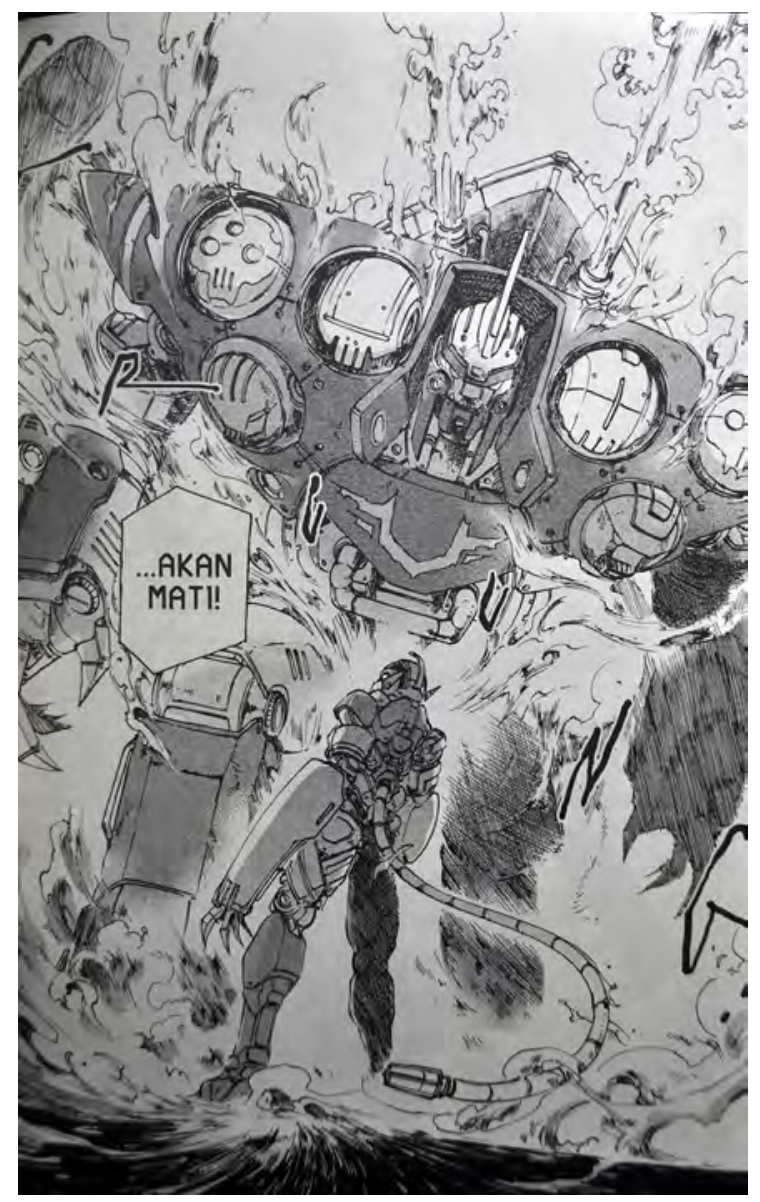

Pertarungan Hanoman 2.0 Melawan Ravana

(Sumber: repro dari buku H2O:Reborn Phase 0.3, karya Sweta Kartika) 